Review

\title{
Twenty-year tracking of lighting savings and power density in the residential sector
}

\author{
Shady Attia ${ }^{\mathrm{a}, *}$, Mohamed Hamdy ${ }^{\mathrm{b}, \mathrm{c}}$, Sherif Ezzeldin ${ }^{\mathrm{d}}$ \\ a Sustainable Buildings Design Lab, Dept. UEE, Faculty of Applied Sciences, Univeristé de Liège, Belgium \\ ${ }^{\mathrm{b}}$ NTNU Norwegian University of Science and Technology, Department of Civil and Transport Engineering, Trondheim, Norway \\ ${ }^{c}$ Department of Mechanical Power Engineering, Helwan University, P.O. Box 11718, Cairo, Egypt \\ d Department of Architectural Engineering E Environmental Design, Arab Academy for Science and Technology and Maritime Transport, AASTMT (Cairo \\ Campus), Egypt
}

\section{A R T I C L E I N F O}

\section{Article history:}

Received 10 December 2016

Received in revised form 15 August 2017

Accepted 16 August 2017

Available online 24 August 2017

\section{Keywords:}

LED lamps

Buildings

Compact fluorescent lamp

Incandescent lamp

Energy efficiency

MENA region

\begin{abstract}
A B S T R A C T
Lighting energy consumption represents a significant percentage of total energy consumption in residential building sector. During the last 20 years, advanced energy-efficient lighting fixtures have been introduced worldwide to conserve the energy consumption in residences. In the Middle East and North Africa (MENA) region, very few studies have been conducted to evaluate the association between the introduced lighting fixtures and the resulted energy savings using valid measurements and verification techniques. This study evaluates the techno-economic impact of replacing new energy efficient lighting in residences in Egypt (a representative MENA region country). A quantitative analysis is applied by tracking the utility bills of 150 residential apartments in Cairo. The average measured power consumption before (1993-1998) and after (2009-2014) installation energy efficient lighting fixtures is analyzed. A building performance simulation model is developed to back the findings. The findings indicate a significant disparity between the estimated savings based on simulation and the real measured savings due to penetration, rebound effect and low quality lamps. Moreover, the findings present an example of quantified benefits of energy efficient lighting, which is very important to inform the decision making of public policy makers, investors and building occupants.
\end{abstract}

(c) 2017 Elsevier B.V. All rights reserved.

\section{Contents}

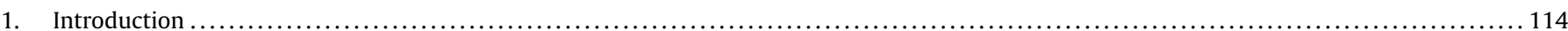

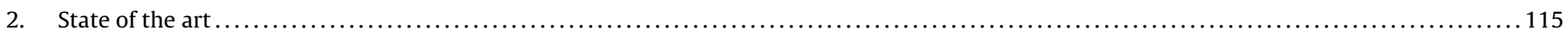

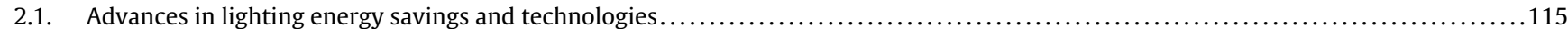

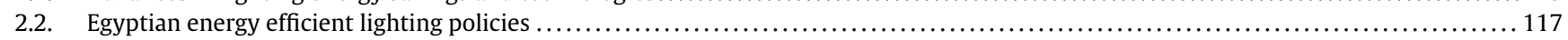

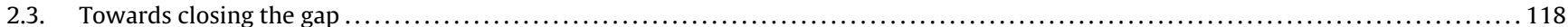

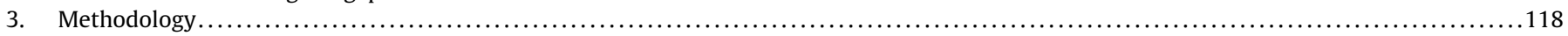

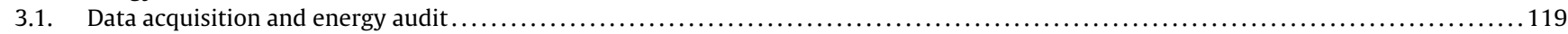

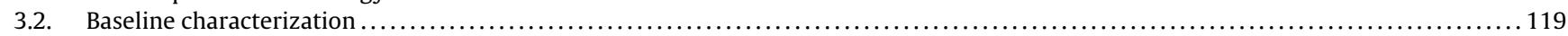

Abbreviations: ASHRAE, American Society of Heating, Refrigerating, and Air-Conditioning Engineers; AC, air conditioning; ANSI, American National Standards Institute;

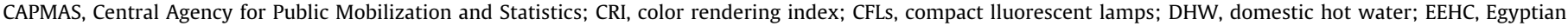

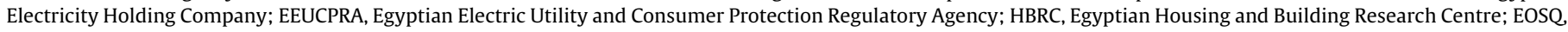

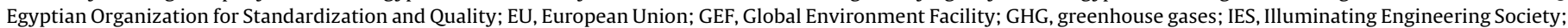

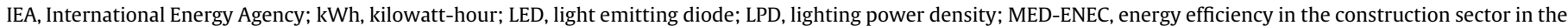

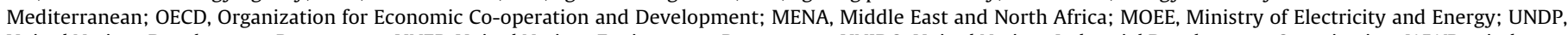

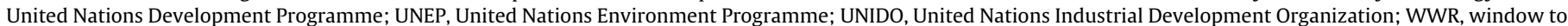
wall ratio.

* Corresponding author at: Univeristé de Liège, Sustainable Buildings Design Lab, Office +0/542, Quartier Polytech 1, Allée de la Découverte 13A, 4000 Liège, Belgium.

E-mail address: shady.attia@ulg.ac.be (S. Attia). 


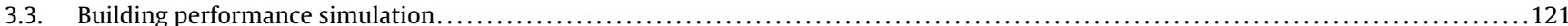

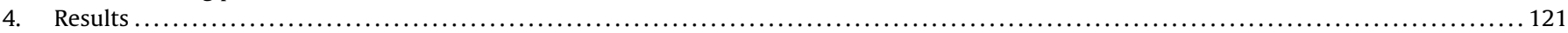

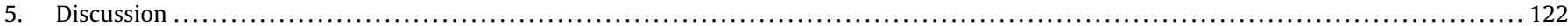

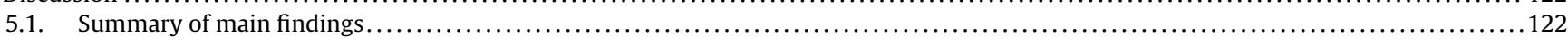

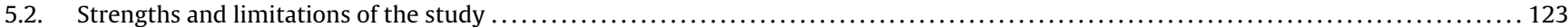

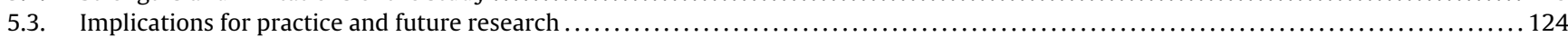

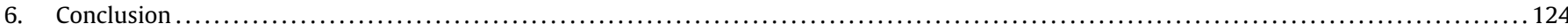

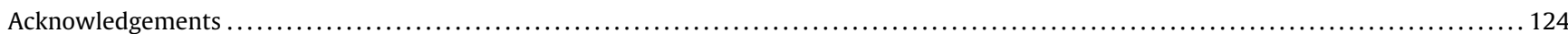



\section{Introduction}

Lighting energy accounts for approximately 19\% (2900 TWH) of the global electric energy consumption. Projections by the International Energy Agency (IEA) show that if governments only rely on current policies, global electricity use for lighting will grow to around 4250 TWh by 2030 , an increase of more than $40 \%$ [1]. The energy sector plays a key role in the Middle East and North Africa's (MENA) economic progress. The Egyptian government faces serious challenges securing energy for all economic activities. During the last 15 years the annual growth rate exceeded $8 \%$, where $85 \%$ of the electricity originates from fossil sources primarily natural gas. The residential building sector is supplied mainly by electricity to meet the cooling, lighting and plug load demands. According to the last governmental statistics, in $2014,43 \%$ of the total electricity consumption was attributed to the building sector [2,3]. The residential building sector is facing a number of challenges, above all is the low construction quality and building energy efficiency. Similar to most MENA countries, the highest energy consumption subsidy is currently within the residential sector, that is why the energy savings in this sector should generate the highest returns to the state budget. Faced with the need to secure reliable and affordable energy sources for the coming decades while maintaining growth, there is a national incentive to move toward a less greenhouse gas (GHG) intensive development path, by becoming more energy efficient and making greater use of the country's potential renewable energy.

Energy efficiency standards and labels are developed for appliances such as refrigerators, freezers, washing machines, air conditioners, electric water heaters, electronic ballasts, and compact fluorescent lamps [4]. In recent years, several measures to promote efficient lighting use were adopted by the Egyptian government. Since 2014, the electricity sector witnessed serious fundamental reforms, reducing the energy subsidy, allowing the private sector to generate electricity, distributing 10 million LED lamps and aiming to replace incandescent lighting fixtures by 2020 [5,6]. According to GEF Evaluation Office an energy efficiency market support was achieved by conducting 193 audits and implementing the recommendations of 20 audits, replicating a compact fluorescent lamp leasing program at Cairo and Canal Electricity Distribution Companies, by promoting and diffusing compact fluorescent lamps with the active participation of the private sector [4].

In Egypt, residential buildings comprise 26.881 .533 households and electrical lighting accounts for $20-35 \%$ of the residential electricity consumption [2]. Between 2012 and 2015, the average lamps' sales was 70 million lamps, representing five major types of lighting lamps that are used in Egypt (Incandescent, Fluorescent, Compact Fluorescent, Halogen, LED lamps) [7]. On the basis of the energy efficiency of lighting project of the United Nations Development Program (UNDP) it is estimated that Egypt sold 260 million lamps in 2010 (excluding street lighting) [8,9]. The project strategy to accelerate market transformation in the residential sector is to sell high-quality CFLs at subsidized prices for which the remaining part can be paid back in installments through regular electricity bills. Among 260 million sold lamps about 35 million (13\%) units were fluorescent tubes and 17 million (7\%) CFLs. The remainder is primarily incandescent light bulbs (GLS) [7]. Fig. 1 illustrates an estimation of the evolution of lamps market in Egypt during the period from 2010 to 2016. The Egyptian authorities and industry could not provide us with actual sales of lighting equipment during that period, due to the lack of central tracking of locally produced and imported lamps sales. There has been a fast growth of fluorescent lamps, particularly compact fluorescent lamps (CFL) and the government introduced a large amount of LED lamps [10].

In the past two decades, many studies have reported the correlation between the decrease of energy consumption by improving the energy efficiency of lighting appliances [11-16]. Most studies investigated the impact of efficient lighting appliances by using estimation methods such as regression analysis models or simulation models [17]. However, there is no published data or knowledge on the measured effect of installing efficient lighting technologies on savings of average middle class households in Egypt. Of particular relevance are the lighting power density and the effect of CFL on long-term savings. It is difficult to quantify the actual savings from energy efficiency measures, which can deter consumer and investors.

Therefore, this study was conducted with the objective of quantifying the effect of replacing incandescent light bulbs with CFL over a period of 20 years. The overall aim is to promote effective energy efficiency of indoor lighting. The research objectives include: i) identification and determination of lighting energy-savings of the residential Egyptian building sector that have been made from 1994 to 2014 and ii) reduction the uncertainty of indoor lighting energy saving by applying evidence based measuring approach. The methodology is based on data acquisition, modeling techniques and a structured survey. Thus the methodology focused on tracking energy efficient lighting savings and power density of 150 representative Cairene apartments. In this study, we tracked and analyzed building's energy performance monthly bills of 150 apartments for a study span of 20 years.

The objective of the study is not to proof that florescent and CFL would result in reductions in energy consumption. Instead, the study aims to identify the real consumption patterns, and the light efficiency in the Egyptian residential sector as an example of a MENA country. By quantifying the benefits of actual savings of energy efficient lighting the study results provide insights and a novel contribution to the public authorities, investors, lighting industry and even citizens in the MENA region. This is a very important step to enable the assessment of the success of energy efficiency implementation policies and identify empirically the barriers in the region. Moreover, the study reports the breakdown of household's energy consumption usage pattern and the share of lighting energy consumption. Therefore, the study results are transferable and can strengthen the regulatory and institutional framework, improve the decision making of public authorities and allow the exploration of accurate financial and energy efficiency 


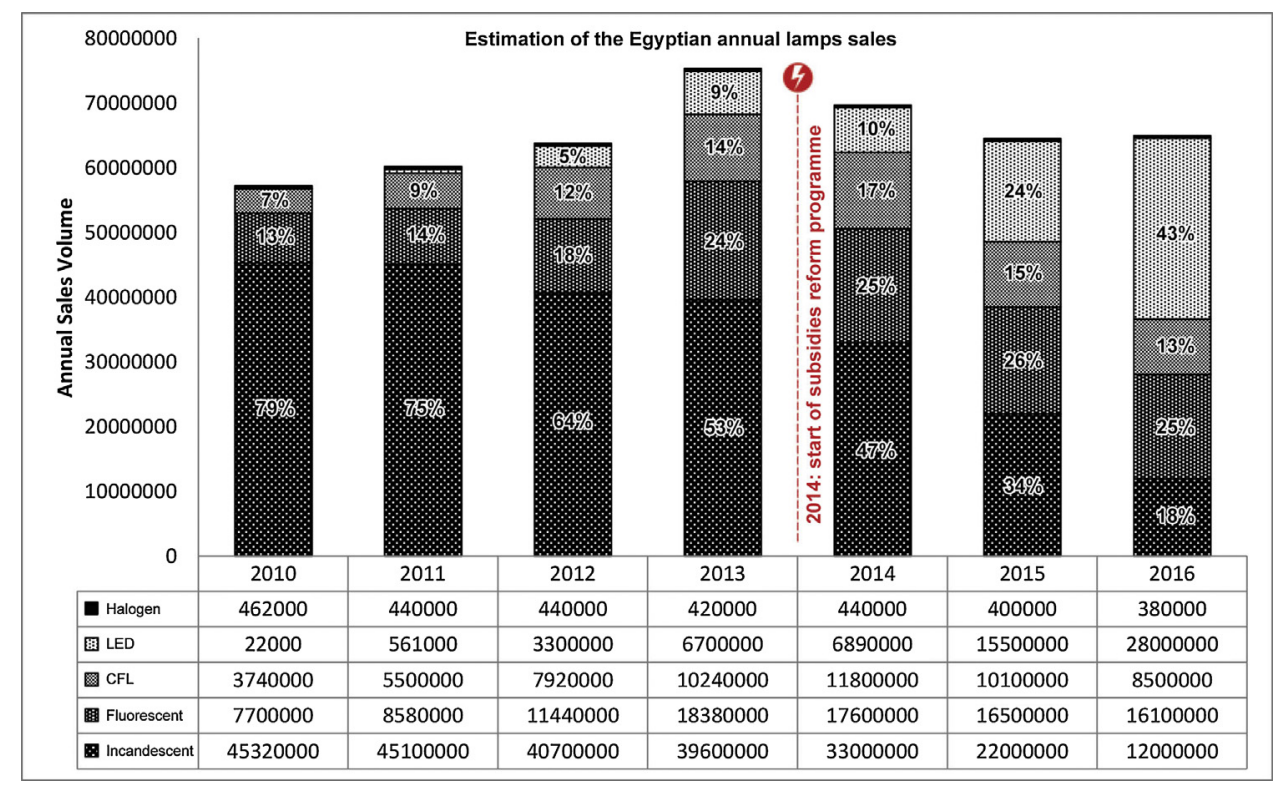

Fig. 1. Estimated sales of lamps in the Egyptian market between 2010 and 2016 (El Sewedy [51], Yassin [7]).

plans for distributing 10 million LED lamps and replacing incandescent lighting fixtures by 2020 in Egypt [5].

This paper is organized into six sections. The first section identifies the research problem within the Egyptian energy efficiency community. The second section provides a research contextualization by presenting a review on the state of the art of energy efficient lighting worldwide and energy efficient lighting policies in Egypt. The third section explains the research methodology, process and tools to generate the results and support the findings. The energy data acquisition results and analysis are discussed in section four. The final two sections are discussing the findings and providing feedback to lighting experts, testing laboratories, policymakers and the lighting industry.

\section{State of the art}

Replacing older lighting with advanced lighting systems can lead to substantial energy savings for electric lighting. Lighting quality and user satisfaction can also be improved to achieve in the same time better visual comfort in residential spaces. To get an overview of advances in lighting energy savings and technologies that are available on the market we present a review of existing advanced lighting systems. For this review, we investigated groups of products that are relevant to the state of the art of lighting energy savings and technologies. The products are selected with the intent of capturing the current state of the market at a given point in time, representing a broad range of performance characteristics. However, the selection does not represent a statistical sample of all available products in the identified group. At the time of investigation (2014), all selected products were compared based on available manufacturer's webpages (2014). Then, we present in Section 2.2 a review of Energy Efficient Lighting Policies in Egypt. Both reviews are aimed to position the research study worldwide and in the local context.

\subsection{Advances in lighting energy savings and technologies}

Human centric lighting represents the next evolution in lighting design. Human centric lighting is defined as the day and electric lighting designed and applied to improve circadian rhythms for alertness, sleep, mood, visual acuity and productivity. Its effective application can increase lighting performance, energy savings and sustainable design. The Illuminating Engineering Society (IES) published in 2013 the TM-24-13 [18], which describes how light spectrum affects visual acuity in interior lighted spaces, and illustrates how spectrally enhanced lighting may be factored into lighting calculations for interior lighting applications. As a consequence, there is rapidly growing variety of products and changing performance characteristics in conjunction with their use to achieve optimum human centric lighting, including primarily the latest generation of dimming and warm-to-cool white Kelvin changing LED troffers, troffer kits, drums, and task lights.

Thirty five years ago the incandescent lamps were the best available option in the market in the Organization for Economic Cooperation and Development OECD countries. It had a perfect color rendering index of 100 with a cheap luminaire. It was the beginning of the nineties when discharge lamps became the basis of many lighting technologies, including neon lights, low-pressure sodium lamps (the type used in outdoor lighting such as streetlamps) and fluorescent lights. Today, the United Nations Environment Programme (UNEP) and Global Environment Facility (GEF) work with developing and emerging countries to implement standards for the lighting energy efficiency to phase-out incandescent light bulbs. Fig. 2 shows the status of phase out of incandescent light bulbs around the world.

Five years later in 1995 the spiral fluorescent tube or the compact fluorescent light (CFL) became the mainstream in OECD countries. Early CFLs were introduced in the mid-1980s in the market at retail prices of \$25-35 [19]. For examples, in the US prices varied sharply depending on different promotions carried out by energy companies. CFLs were expensive, big and bulky, they did not fit well into fixtures, and they had low light output and inconsistent performance [19]. Since the mid-1990s, CFL performance, price, efficiency (75\% less energy use than incandescent lamp) and lifetime (lasting about 10 times longer) improved and have made them a viable option for residents. Nearly 30 years after CFLs were first introduced on the market, an ENERGY STAR ${ }^{\circledR}$ CFL costs as little as $\$ 1.74$ per bulb when purchased in a four-pack [19].

Today one of the fastest developing lighting technologies and most efficient lights is the light-emitting diode (LED). As LEDs have evolved in the architectural lighting market, integral LED lamps have become obvious options for replacing low-efficacy fluorescent and halogen lamps in the recent years. Linear LED lamps (also called T8 LEDs or T8 LED replacement lamps) are competing with a 

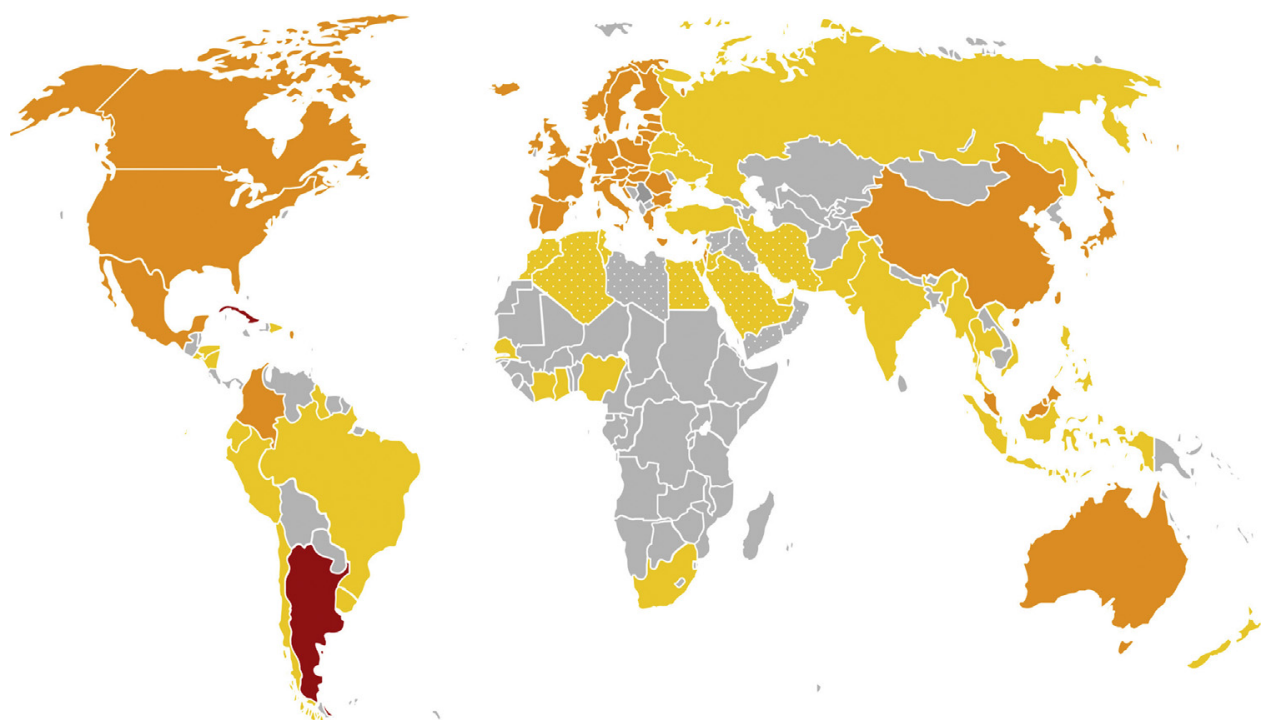

Limited exchange programs

Partial ban

Full ban

MENA Region

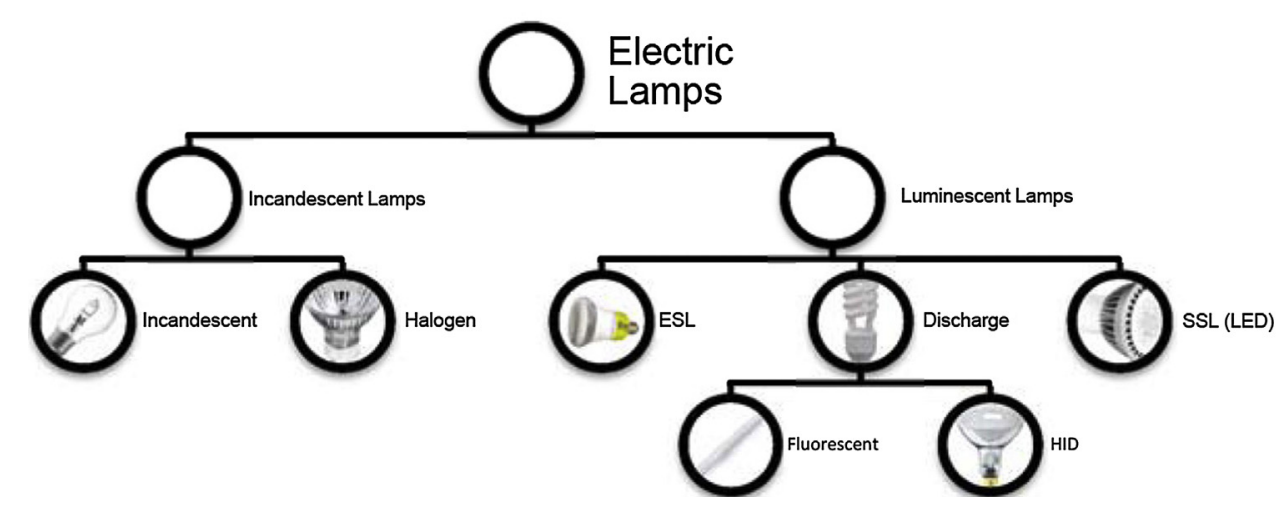

Fig. 2. Phase out of incandescent light bulbs worldwide in 2016 adapted from (UNDP [53]) and overview of lamp type's family tree.

Table 1

Types of domestic appliances and their average power and operation hours.

\begin{tabular}{|c|c|c|c|c|c|c|c|c|c|}
\hline $\begin{array}{l}\text { Performance } \\
\text { Description }\end{array}$ & Incandescent & $\begin{array}{l}\text { Candle } \\
\text { Incandescent }\end{array}$ & Halogen & $\begin{array}{l}\text { Fluorescent } \\
\text { TL } 8\end{array}$ & $\begin{array}{l}\text { Compact } \\
\text { Fluorescent }\end{array}$ & LED GLS & LED spotlight & Florescent T5 & LED DT8 \\
\hline Code in Plan & InC & $\mathrm{CnL}$ & Hal & FluT8 & $\mathrm{CfL}$ & LeD & LeD Pin & FluT5 & LeDT8 \\
\hline Color Temp. (Kelvin) & $2700 \mathrm{~K}$ & $2700 \mathrm{~K}$ & $3000 \mathrm{~K}$ & $3000 \mathrm{~K}-6500 \mathrm{~K}$ & $2700 \mathrm{~K}-6500 \mathrm{~K}$ & $2700 \mathrm{~K}-5000 \mathrm{~K}$ & $2700 \mathrm{~K}-6500$ & $2700 \mathrm{~K}-6500$ & $2700 \mathrm{~K}-6500$ \\
\hline Life Span h & 1000 & 1000 & 5000 & 20,000 & 10,00 & 45,000 & 45,000 & 50,000 & 50,000 \\
\hline Energy Use & $60 \mathrm{~W}$ & $25 \mathrm{~W}$ & $60 \mathrm{~W}$ & $30-40 \mathrm{~W}$ & $20 \mathrm{~W}$ & $10 \mathrm{~W}$ & $8 \mathrm{~W}$ & $22 \mathrm{~W}$ & $15 \mathrm{~W}$ \\
\hline Sales in OECD & Limited & Limited & Low & Limited & Medium & High & Medium & High & Low \\
\hline Sales in Egypt \& MENA & Medium & High & Medium & High & Medium & Limited & Limited & Limited & Limited \\
\hline
\end{tabular}

compulsory technology that is familiar, efficient, interchangeable, and cost-effective. Linear LED lamps are increasingly considered by electricians and facility managers as obvious energy-efficient replacements for the linear fluorescent lamp. Linear LED lamps are often promoted by manufacturers and sales agents as an easy retrofit option, with only minor retrofit labor needed, equivalent lighting performance to fluorescent, dramatic energy savings and resulting return on investment, and/or almost negligible relamping costs because of long life. It should be noted that many manufacturers are targeting T8 fluorescent (FL) lamps, which in their premium form already boast efficacy of greater than $90 \mathrm{~lm} / \mathrm{W}$, excellent lumen maintenance, and long life of up to $80,000 \mathrm{~h}$ when paired with well-engineered electronic ballasts. Fig. 2 and Table 1 provides an overview of the main lamp type's family tree and their characteristics that evolved during the last 50 years.

Parallel to the advances in lighting energy savings and technologies, very few studies that measured and modeled the lighting energy savings are showing a very large range of variation in the OECD countries. This includes the work of Stokes et al. [20] and Deltour et al. [21]. However, almost no study measured the impact of those advances on energy consumption in emerging and developing countries. Therefore, in this paper we investigate and measure the impact of advances in lighting energy savings and technologies in Egypt as a representative MENA region country. 


\subsection{Egyptian energy efficient lighting policies}

Egypt, similar to many MENA region countries, did join the world energy efficiency movement recently. The 1973 Arab Oil Embargo was not a reason to consider energy efficiency in the country. On the opposite, the heavy energy price subsidy constrained an investment in the energy sector and the potential of GHG reduction was not properly exploited. It was until the establishment of the Global Environment Facility (GEF) in 1991 as a pilot program in the World Bank in partnership with United Nations Development Program (UNDP) and United Nations Environment Program that Egypt started to address energy efficiency and environmental issues.

From 1991 until 2010, the Energy Efficiency Improvement and Greenhouse Gas Reduction Project was executed by the Egyptian Electricity Holding Company (EEHC), Ministry of Electricity and Energy (MOEE) and supported with a grant from the Global Environment Facility (GEF) of the United Nations Development Program (UNDP). The development objective was to meet suppressed and still growing power and energy demands through reliable, efficient and rational consumption patterns, thereby reducing greenhouse gas emissions [22]. The project's main achievements have been the encouragement of Egyptian manufacturers to manufacture CFL locally (6 factories), public awareness program and cooperation with NGOs and power distribution companies. The Egyptian Organization for Standardization and Quality has issued specification number of operation and safety aspects and 12 million CFLs (20 W) have been sold through the electricity distribution companies for half of their price between 2006 and 2010 [9,6]. Also the project succeeded to provide support given to technical testing labs of CFLs and a Ministerial Decree on specifications of energy labels for CFLs but without a clear enforcement mechanism.

In 2002, a ministerial decree was issued for the enforcement of the standards and labeling program for the refrigerators, freezers, washing machines, and air conditioners. In 2006, the Energy Code for Residential Buildings was developed and in 2008 a standard for CFLs and electronic ballasts was issued. Lighting system and air conditioner testing labs are playing a major role in practice. In 2007, a newly structured National Committee on Climate Change has been created. The following publications review and summarize chronologically the key publication energy efficient lighting savings and power density in the Egyptian building sector. As a consequence, several studies have been published addressing lighting energy efficiency in Egypt between 2006 and 2016 and will be listed below:

In 2006, the Housing and Building National Research Center (HBRC) supported by the UNDP published the residential building energy standard for Egypt [23]. Several prototypical residential buildings have been developed that are used by the code working group to evaluate the energy savings from a comprehensive set of envelope and HVAC system measures Attia et al. [29,34]. Chapter 7 of the residential building energy standard sets minimum efficiency requirements on the electric lighting system, including the lighting power density, lighting intensity requirements, life span and properties of lighting fixtures [23]. The main problem with this code is that it is not enforced by the state. In practice, there is no compliance with its requirements for new public or private housing projects [24].

El Mohimen et al. analyzed the daylight benefits for office buildings [17]. A parametric study compared the impact of various daylighting control strategies and WWR values on the total building electricity use for clear double-pane reflective glazing. The study noted the importance of reducing the WWR to 0.2 to guarantee maximum daylight autonomy while reducing the peak cooling loads and electricity demand. However, the study focused mainly on office buildings and did not quantify the impact of daylighting on electric lighting and the average electricity use for lighting.
Khalil [25] presented in 2006 the results of one of the first residential energy surveys conducted in Cairo. The survey was conducted in 1998 with a sample size was 2634 households distributed among 16 areas in Cairo. The degree of saturation of different electrical appliance was reported, however, lighting fixtures were not included. The study presented specific energy consumption and average demand in residential buildings.

In 2009, Attia et al. [26] conducted a field survey to estimate the typical electric consumption rate for typical apartment blocks in Cairo aiming to investigate the potentials and impact of energy efficient retrofits. The study focused on overall energy use intensity. The study presented a qualitative description of occupancy pattern and operation schedules of electrical appliances. The field survey results classified the major appliances in each household. Lighting fixtures were conventional incandescent lamps. Other typical appliances included ceiling and standing fans, personal computers, microwave oven, television, and stereo. Unfortunately, the study did not quantify or mention the electric lighting share in the energy breakdown.

In 2009, the GEF launched the UNEP en.lighten initiative, in collaboration with private sector partners to provide industrial knowledge (Philips and Osram), as well as the participation of UNDP, UNIDO, the World Bank and the Chinese National Lighting Test Center (NLTC). The main objective of the initiative is to hasten the global transition towards more efficient lighting, on the basis of its benefits for climate change mitigation, energy savings and financial savings [27]. In this context, en.lighten, in conjunction with the UNEP launched in 2011 a platform on Energy Efficiency for Lighting \& Appliances in Egypt [28].

One of the important publications of this review is the UNDP project document entitled 'Improving the energy efficiency of lighting and other appliances' released in 2011. The document reports that lighting accounts for over 20\% of Egypt's total electricity consumption where incandescent lamps account for $94 \%$ of all lamps sales [8]. The document identified the sales volume of lamps in Egypt and proposed an annual growth rate of 5\%. The document highlights the barriers to increase the market penetration of energy efficient lighting in Egypt and the market transformation targets of the project. The document addresses the performance quality of CFL lamps and their standards including limiting the mercury content to $5 \mathrm{mg}$ of mercury per lamp and creating a waste management and recycling plan. The document foresees energy savings potential of energy efficient lighting up to $13 \%$ of projected national electricity demand by 2020 and $17 \%$ by 2030 [8]. However, the baseline scenario for the electricity demand, including lighting, did not report annual lighting power density or electricity use for lighting in the building sector. In the report, most presented information and assumptions on energy saving potential were not reported. With the simplifying assumptions reported in this document we could not find real performance values, which set the UNDP project document at low accuracy and reliability.

In 2012, Attia et al. reported the results of surveying 1500 apartments in Alexandria, Cairo and Asyut [29]. The study provided detailed lighting power density values and schedules. The dominant types of lamps used were incandescent lamps and fluorescent tubes. According to the study findings, the average lighting power intensity for living room and bedrooms was 17 and $13 \mathrm{~W} / \mathrm{m}^{2}$, respectively. The other spaces of the investigated apartments had an intensity of $9 \mathrm{~W} / \mathrm{m}^{2}$. However the study did not provide a breakdown of energy consumption and operation modes of electric lighting. More importantly, the study did not investigate the energy saving potential of electric lighting. The study focused more the development of a benchmark for residential buildings and overall average energy use intensity per apartment.

In 2014, Nassief [30] evaluated the total electricity consumption of a flat in Cairo, Alexandria and Aswan. The study focus was investi- 


\section{Comparison of Technology Adoption in OECD and MENA Countries}



Fig. 3. Comparison of lighting technology adaption in MENA and OCED countries.

gating the effect of varying HVAC systems and envelope. Similarly in 2015, Banhardt reported the results of a monitoring study on air conditioned apartments in El Gouna [31]. However, both studies did not provide sufficient details on the energy consumption breakdown and the share or influence of artificial lighting on the overall consumption.

This review generally shows that energy efficient lighting savings were never quantified or monitored for Egyptian households. Many studies addressed improving the electric lighting system i.e. by replacing or planning the electric lighting installation with energy-efficient fluorescent lamps-luminaires and CFL (or even LED lamps). In Egypt, energy saving concepts is popular over the last decade within the government. The Egyptian Ministry of Electricity has been promoting the use of energy saving lamps, including the LFL and the CFL [6]. However, the real effect or impact of energy efficiency lighting is not presented in any study. Moreover, no study reported the breakdown of household's energy consumption and the share of lighting energy consumption.

\subsection{Towards closing the gap}

Finally, this review provided a snapshot on the latest advances in energy savings and technologies in lighting in OECD countries versus the current history and situation of energy efficient lighting policies in Egypt. Our review estimates a 10-15 years gap between the OECD and MENA countries. As shown in Fig. 3, it took 7 years until CFLs got used by one-quarter of households in OECD countries and 18 years until CFLs got used by one-quarter of households in the MENA region. Then, it took 4 years until LED lamps got used by one-quarter of households in OECD countries and 13 years until LED lamps got used by one-quarter of households in the MENA region. We think that the cause of the current gap is explained by heavy subsidy program that peaked across the MENA region starting the independence years. We observe during the last years a trend towards closing the gap due to fast developing pace of efficient lighting technologies today, the light-emitting diode (or LED).

In this context we are looking to quantify the benefits of energy efficiency measures in residential buildings and provide reliable data on the actual savings. The research outcomes will influence policies that ensure closing the energy efficiency lighting gap. According to the literature review, the efficiency and penetration of households' electric lighting installation in Egypt remains unknown, especially with, with the state intention to spread the use of LED technology in 2014. In 2015, a tender has been issued by the Ministry of Electricity for procurement of 10 million LED lamps to be distributed to residential customers by electricity distribution companies through installments added to the electricity bill [6]. Therefore, it is essential to track energy performance and to check whether the GHG emission reduction targets are being met. Accurate data can inform timely decision makers regarding the impact of past and future energy efficient lighting.

\section{Methodology}

We aimed to find a representative sample of Egyptian middle class households. For this study we collected and compared data about the effect of installing fluorescent lamps and compact fluorescent lamps (CFL) on the energy savings of middle class residential households in Cairo. The apartments had to represent middle class families with 3-5 children, connected to the natural gas grid for cooking and domestic hot water, representing typical Egyptian middle class households, all located in Al-Bassatiyn south east of Cairo (ASHRAE Zone 2A). The specific target group was upper middle -income families that are able to invest in CFLs due to their still relatively high costs, when compared to the income level of the families and their current electricity tariff. According to the 2012 census, the number of customers in this group is 12 million, which represents over $55 \%$ of all residential customers in the country (estimated at 21.2 million). This was based 2012 survey collected data from 12,083 households. The specific selection was based on examining the energy bills of more than 4500 apartments provided to us by South Cairo Electricity Distribution Company. The final sample for analysis was 180 rented apartments located in multistory building blocks in South-East Cairo.

Four major steps identify the research methodology. Firstly, the data acquisition of monthly electric energy consumption of 180 apartments was conducted based on the utility bills from 1993 until 
2014. Secondly, an audit and survey for lighting fixtures and appliances, including their wattages, were conducted for each apartment for the years 2014. Thirdly, the baseline was determined by calculating the average electric energy consumption for lighting from 1993 to 1998 . Based on the audits the average plug loads consumption was determined and extracted from the monthly energy values allowing us to approximate accurately the installed baseline lighting energy. The final step of the methodology was to build a simulation model to estimate the lighting power density and validate step three. The following section explains each step in detail.

\subsection{Data acquisition and energy audit}

In Egypt, electric energy consumption is commonly tracked on a monthly basis and is accessible on the state owned electric utility companies. For this study, total energy consumption bills were tracked for every apartment from 1993 to 1998 representing Dataset I and 2009-2014 representing Dataset II. To verify that the data set is complete and that it yields credible results we investigated every monthly reading. For some apartments monthly reading had been missing. However, we discovered that the following month would include the total consumption of both months. In such cases we had to reconcile the missing data by estimating the missing month reading value to avoid gaps.

In the same time, we collected and calculated the data for each apartment manually, through a detailed audit of lighting fixtures, to improve our forecasts of energy consumptions. The final sample for analysis focused on apartment blocks. 180 rented apartments were eligible for this study with an access to their electricity energy bills and occupants. All blocks were built between 1985 and 1990, and made of concrete structural skeleton and brick walls with a typical $3 \mathrm{~m}$ high ceiling. All investigated apartments had no insulation, AC units or electric heaters (no cooling or heating consumption). All types of fans were included in the plug loads for each apartment and a pump is used collectively for each building block with a separate electric meter. All investigated apartments were rented and occupied by users between 1993 and 2014. All examined apartments had to have an electricity meter accessible from inside or outside the apartment and assumed that lighting retrofits were made by the apartment tenants.Only then, each apartment was examined through a walkthrough visit with the use of an interview questionnaire designed for the study. Respondents completed 3 questionnaires that assessed variables that could influence energy consumption (e.g., appliances, acclimatization systems, fans and light appliances). After filling in the questionnaire to describe the household in 1994, 2004 and 2014 interviews were conducted for each household's residents to complete and validate any details. Occupants were asked about the fuel used for cooking and DHW and if there was any heating or AC equipment used in their homes.
Table 2

Benchmark model and energy efficiency characteristics.

\begin{tabular}{lll}
\hline & Properties & Benchmark characteristics \\
\hline 1 & Orientation & 0 \\
2 & Shape & Rectangular $(12 \mathrm{~m} \times 10 \mathrm{~m})$ \\
3 & Floor Height & $3 \mathrm{~m}$ height \\
4 & Roof U-value & $\mathrm{U}=1 \mathrm{~W} / \mathrm{m}^{2} \mathrm{~K}$ \\
5 & Wall U-value & $\mathrm{U}=2 \mathrm{~W} / \mathrm{m}^{2} \mathrm{~K}$ (no radiant barrier) \\
6 & WWR & $35 \%$ \\
7 & Window system & $\mathrm{U}=5.8 \mathrm{~W} / \mathrm{m}^{2} \mathrm{~K}$, SHGC: $0.6-$ Single Pane \\
& & in aluminium frame, Tv $=0.86$ \\
8 & Operable Shading & operable window without exterior \\
& & shading \\
9 & Overhang & None \\
10 & Night insulation & Not considered \\
11 & People Density & $0.033 \mathrm{people} / \mathrm{m}^{2}$ \\
12 & Infiltration: & $1.5 \mathrm{ACH}$ \\
13 & Internal heat gain & $19 \mathrm{~W} / \mathrm{m}^{2}$ from lighting, $12 \mathrm{~W} / \mathrm{m}^{2}$ from \\
& & appliances \\
14 & Lighting Power Density & $10 \mathrm{kWh} / \mathrm{m}^{2} \mathrm{a}-100 \mathrm{~m}^{2}$ \\
\hline
\end{tabular}

a Constant internal gains were obtained from annual equipment and lighting energy use, using conventional vs. energy-efficient appliances, $0.8 \mathrm{~W} / \mathrm{m}^{2}$ (incandescent) vs. $0.17 \mathrm{~W} / \mathrm{m}^{2}$ (CFL) Installed lighting wattage and identical usage profiles for the base-case and maximum efficiency option.

Lighting fixtures types of each apartment were investigated including their power density (in watt) and intensity (in lux) to help determine the typical lighting levels and on/off periods. The walkthrough visits were conducted for 180 apartments on July 2014 and made an accurate count of each light fixture with each space of the apartments. Task lighting also was accurately counted and documented for each room. Building drawings and architectural plans helped to determine the planned lighting power density (LPD) for each apartment.

\subsection{Baseline characterization}

Step three focused on creating a representative baseline by translating the audit and questionnaire results into a calculated baseline model. Fig. 4 illustrates a baseline apartment that represents the 180 investigated apartments. The apartments are located in building blocks and clusters all planned by Maadi Company for Development and Reconstruction and fall between on both side of a street named Street Al Gazaer. For this study we selected a benchmark based on a recent research [29], to develop a benchmark model for the Egyptian residential buildings sector. The benchmark was developed to describe the electricity use profiles for lighting, domestic hot water and appliances in respect to buildings layout and construction (see Table 4). As shown in Fig. 4, different lighting technologies are traced and drawn during the 1994 and 2014 audits. The reference dwelling's lighting solutions comparison is described in Tables 2 and 3. In order to determine the baseline we calculated

Table 3

Comparative lighting type's characterization for 150 apartments in 1994 and 2014.

\begin{tabular}{|c|c|c|c|c|}
\hline Lighting Type & Average units per apartment- $100 \mathrm{~m}^{2}$ & Capacity lumens & Average Power Watt & Daily Operation Hours \\
\hline \multicolumn{5}{|l|}{1994} \\
\hline Incandescent & 9.5 & $\mathrm{n} / \mathrm{a}$ & 75 & 7 \\
\hline Fluorescent $(120 \mathrm{~cm})$ & 2.5 & $\mathrm{n} / \mathrm{a}$ & 45 & 5 \\
\hline Fluorescent $(60 \mathrm{~cm})$ & - & - & - & - \\
\hline $\begin{array}{l}\text { Compact Fluorescent } \\
\text { Halogen }\end{array}$ & 0.4 & $\mathrm{n} / \mathrm{a}$ & 100 & 0.1 \\
\hline \multicolumn{5}{|l|}{2014} \\
\hline Incandescent & 3 & 960 & 60 & 7 \\
\hline Fluorescent $(120 \mathrm{~cm})$ & 1.8 & & 45 & 11 \\
\hline Fluorescent $(60 \mathrm{~cm})$ & 2 & & 22 & 5 \\
\hline Compact Fluorescent & 7 & 1300 & 18 & 3 \\
\hline Halogen & 0.6 & 1400 & 100 & 0.1 \\
\hline LED & 0.2 & & 8 & 8 \\
\hline
\end{tabular}




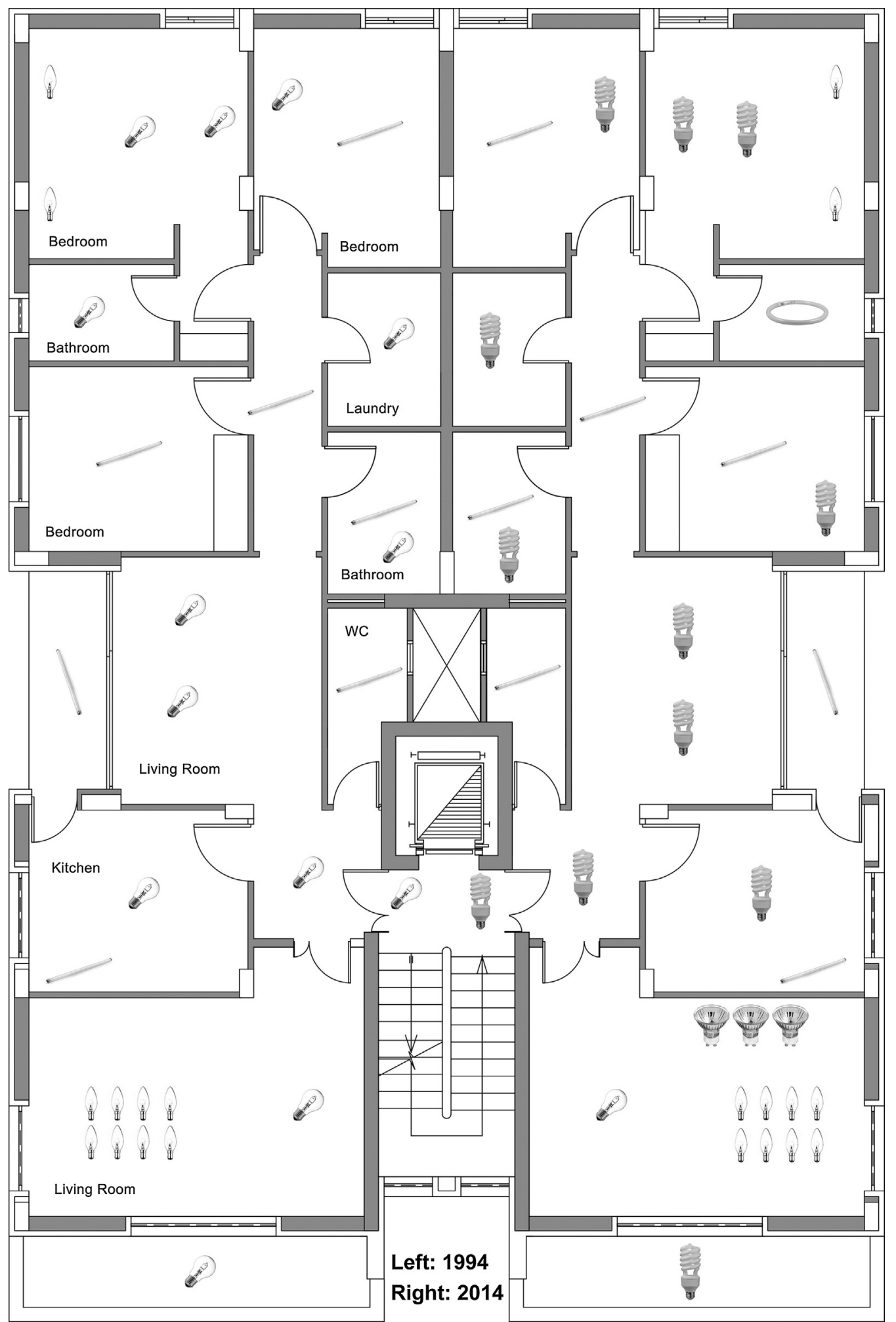

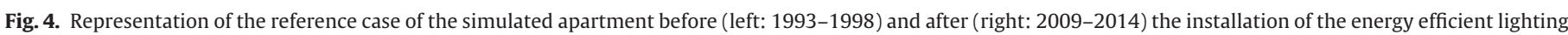
fixtures.

the average (mean value) electric energy consumption for lighting from 1993 to 1998 . Then we estimated the average monthly plug loads based on the 1994 questionnaire. We subtracted the average calculated electric consumption for the baseline from the average annual energy consumption provided from the energy bills. With the help of the questionnaire results (listed in Table 4) the average plug loads consumption was determined and extracted from the monthly energy values from Dataset I. This allowed us to approximate the installed baseline lighting energy. The questionnaire included an extensive study of available lamps and luminaires and illuminance values in the working planes, kitchen, restroom, living room and bedrooms. For the lamps, the studied characteristics were start-up time, the color and color rendering, the shape and the bases. The procedure was repeated to estimate the plug 
Table 4

Types of domestic appliances and their average power and operation hours.

\begin{tabular}{|c|c|c|}
\hline Appliance & Watt & Daily Operating Hours \\
\hline \multicolumn{3}{|l|}{1994} \\
\hline Exhaust fan & - & - \\
\hline Satellite decoder & - & - \\
\hline Cell Phone charger & - & - \\
\hline Phone charger & 3 & 3 \\
\hline Electric Iron & 1100 & 0.1 \\
\hline Vacuum cleaner & 630 & 0.1 \\
\hline Fans (2) & 100 & 3 \\
\hline Television & 180 & 5 \\
\hline Washing machine & 600 & 0.2 \\
\hline Refrigerator & 380 & 24 \\
\hline Kettle & - & - \\
\hline PC/Laptop (1) & $300 /-$ & 2 \\
\hline Mixer & 127 & 0.05 \\
\hline Stereo & 100 & 0.1 \\
\hline \multicolumn{3}{|l|}{2014} \\
\hline Exhaust fan & 150 & 3 \\
\hline Cable Box & 20 & 7 \\
\hline Cell Phone charger & 5 & 8 \\
\hline Phone charger & 3 & 24 \\
\hline Electric Iron & 1100 & 0.1 \\
\hline Vacuum cleaner & 630 & 0.1 \\
\hline Fans (6) & 100 & 3 \\
\hline Freezer & 450 & 24 \\
\hline Television & 100 & 6 \\
\hline Washing machine & 550 & 0.2 \\
\hline Refrigerator & 300 & 24 \\
\hline Kettle & 1800 & 0.1 \\
\hline PC/Laptop (1/2) & $300 / 90$ & $1 / 3$ \\
\hline Mixer & 127 & 0.05 \\
\hline Toaster & 750 & 0.1 \\
\hline
\end{tabular}

loads of Dataset II based on the audit of 2014. Then we compared the average monthly kWh consumption of dataset I and II. Consumption change was treated as a continuous variable, calculated as difference between measurements. The approximate installed baseline lighting energy was determined based on the monthly consumption comparison.

\subsection{Building performance simulation}

In order to extend the dataset analysis and validate the average lighting power density a simulation case study was conducted. Each of the questionnaires and the self-report audit provided estimates of occupancy rates and activity schedules over the year 1994 and 2014. A reference dwelling was selected to validate the lighting power density for the year 1994 and 2014. Cairo weather file was selected for this case study [32]. Cairo is part of the mid-latitude global desert zone and its climate is considered extremely hot and dry according to the Köppen Classification (Group B) [33]. According to ASHRAE climate classification Cairo is hot humid (2A). The selected baseline represents one of the investigated flat apartments in South-East Cairo (see Section 3.2). Table 2 and Fig. 4 list the baseline (1994) characteristics in addition to measures for estimating lighting energy. ZEBO and EnergyPlus building performance simulation (BPS) programs were used to perform the analysis [34,35]. Each released version of EnergyPlus undergoes two major types of validation tests: analytical tests, according to ASHRAE Research Projects 865 and 1052, and comparative tests, according to ANSI/ASHRAE 140 [36] and IEA SHC Task34/Annex43 BESTest method [37]. Within the capability of EnergyPlus, the building models were set up with a priority to reproduce quite in detail the geometrical features of the building and the physical phenomena that determine the electric energy consumption of the building.

The tasks performed for simulation included: simulation of a benchmark apartment, energy breakdown for plug loads and lighting. The simulation started with determining the annual average energy use excluding space heating and cooling to determine user's electric consumption patterns and spikes. By this, the research acquired a starting point for comparing the electric energy consumption monthly profiles with the collected data. The baseline model was calibrated to compare the monthly energy consumption figures in 1994 and 2014. Then, the monthly energy consumption values were normalized. The detailed modeling of the electric energy uses allowed us to effectively generate a monthly lighting consumption profile and lighting power density for the year 1994 and 2014. Typical densities and schedules data collected from the audits were used to model occupancy, lighting, and equipment. For the 1994 baseline, incandescent luminaires were used to represent standard residential installations. Typical Egyptian residential building occupancy schedules are used to define the operation patterns for the electrical lighting system. Monthly lighting energy consumption was calibrated to average values extracted from Dataset I and II. This resulted in estimated values of electric lighting consumption of the other months. The following step was to create the 2014 proposed model with fluorescent and CFL luminaires to represent the change in fixture usage for residential buildings. The simulation results were calibrated until the more energy efficient consumption monthly profile was generated.

\section{Results}

The results of energy data acquisition indicate that the average electric consumption for Dataset I (1993-1998) was $26 \mathrm{kWh} / \mathrm{m}^{2} / \mathrm{a}$ and $24 \mathrm{kWh} / \mathrm{m}^{2} /$ a Dataset II (2009-2014) (see Fig. 5). The energy audit included an inventory of electrical appliances as shown in Table 1 . The saturation rates and penetration rates of lighting fixtures were determined based on the 1994 and 2014 audit and walkthrough of 180 apartments. Between the 1994 and 2014 audits, major changes in the structure of households appeared even some families have moved out. All apartment tenants made lighting retrofits. Our eligibility criteria excluded families who witnessed a sharp change in occupancy rate or purchased AC units or electric heaters over the 20 years period. This resulted in the decreased of study apartments from 180 to 150 . The survey results indicate an average occupancy of 3.1, 4.4, 3.6 people per apartment respectively for the year 1994, 2004 and 2014, which was considered as consistent. The characteristics of families are mainly nuclear families where an adult would be at home during daytime, while other family members would be at work or at school. By nuclear family we mean a family group consisting of a pair of adults and their children.

Data generated by the audit shows that the lighting power density and fixtures types installed in 1994 compared to 2014 varied significantly. The dominant types of lamps used in 1994 were mainly incandescent lamps with fluorescent tubes $(120 \mathrm{~cm})$. On the other side, the 2014 audit results indicate that CFL lamps were the most dominant lamps while incandescent units still existed in additional to halogen lamps. Table 3, shows a breakdown of average lighting fixtures types found in the apartments. In average, an apartment would have 12.4 lamps per $100 \mathrm{~m}^{2}$ of apartment in 1994 and 14.6 lamps per $100 \mathrm{~m}^{2}$ of apartment in 2014. The increase was mainly due to the proliferation of task lightings and individual lighting units. Also occupants indicated the main reason to switch to CFL and florescent lamps is the increase of energy prices in the last 20 years. Fig. 6 shows daily profiles of lighting use for a typical living and dining room and typical bedroom based on the time of presence of individual households members reported in the survey. The difference between the weekdays and weekends in the living room is due to male's absence.

In order to determine the baseline we estimated the plug load intensities and their operation hours based on an inventory of elec- 


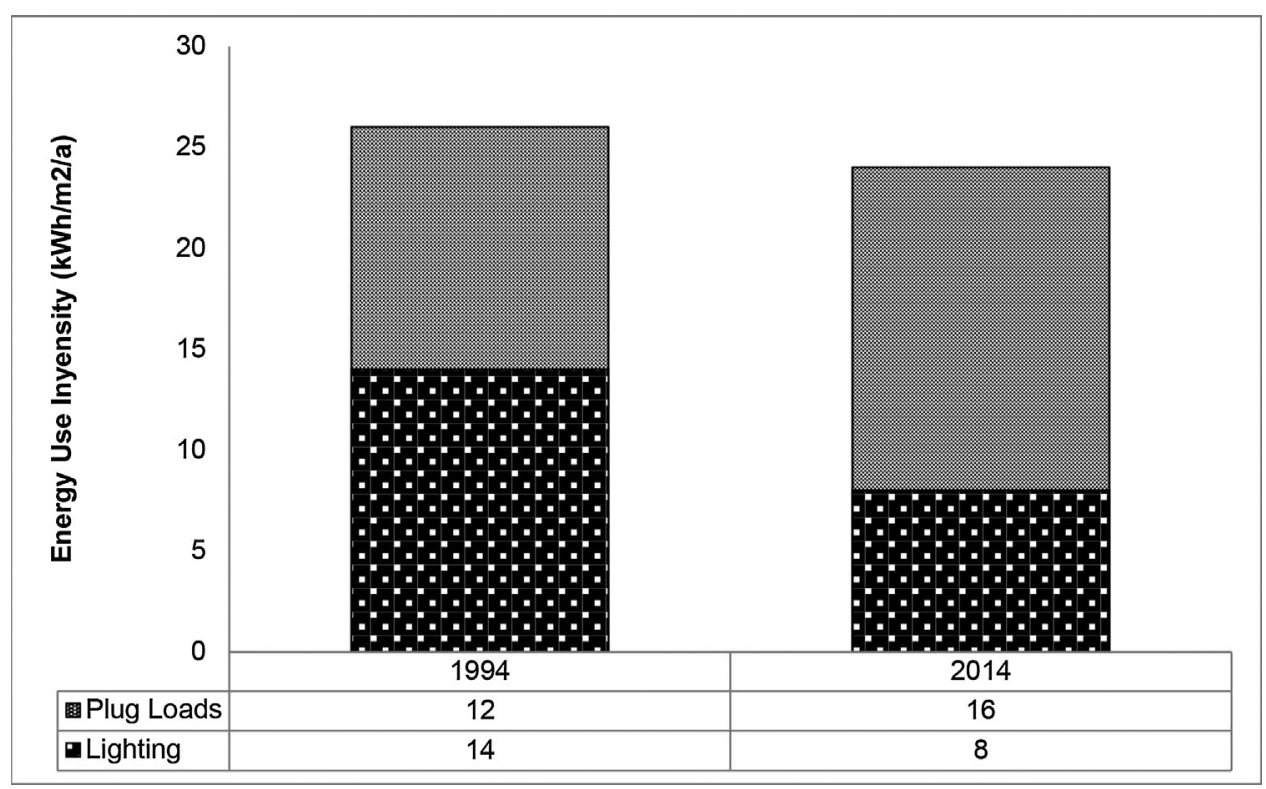

Fig. 5. Average electric consumption for Dataset I (1993-1998) and Dataset II (2009-2014) including electrical appliances.

Weekday
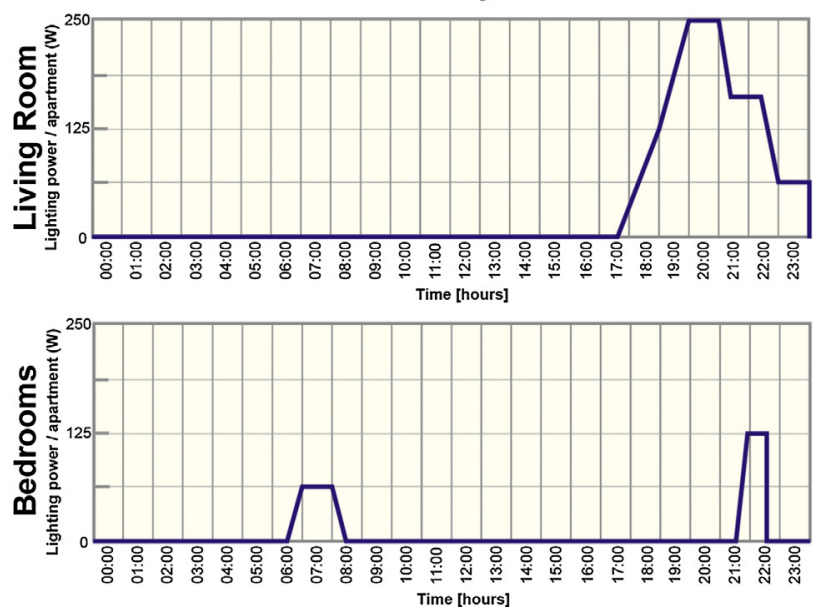
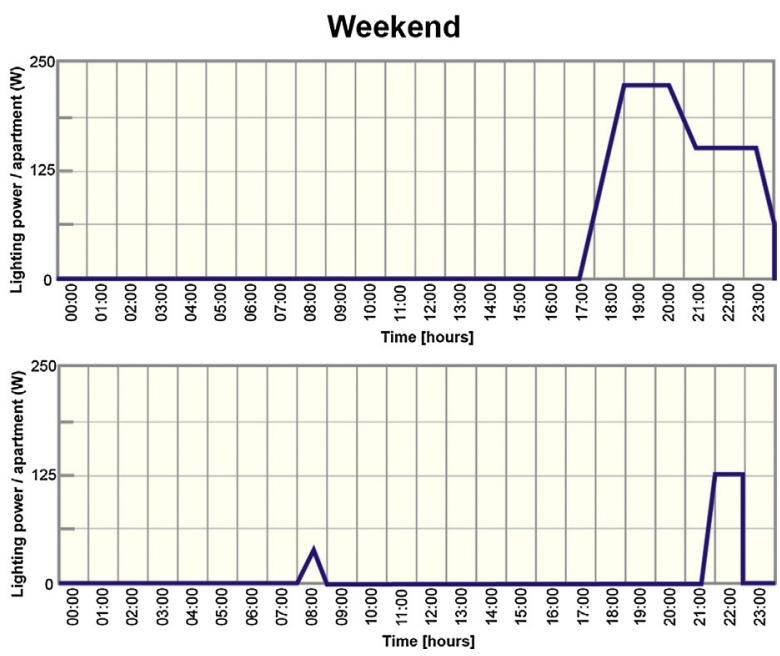

Fig. 6. Profiles of lighting use for a typical living and dining room and typical bedroom.

trical appliances were included in the field survey. The saturation rates and penetration were determined based on the audit findings. The average plug load power intensity in 1994 was $9-11 \mathrm{~W} / \mathrm{m}^{2}$ and in 2014 was $13-15 \mathrm{~W} / \mathrm{m}^{2}$. The result indicates a serious increase of residential plug loads due to the increase of electrical appliances owner ship per household. Table 3 summarizes only those types of domestic appliances that have a saturation rate higher than $50 \%$ from the surveyed sample.

After determining the average plug load power density we subtracted these values from the average electric consumption values of Dataset I and II. At baseline, Dataset I was analyzed with respect to lighting fixtures types and monthly consumption. The simulation model allowed us to validate the calculation results and examine the monthly and annually consumption profiles. The average consumption for electric lighting in 1994 was $14 \mathrm{kWh} / \mathrm{m}^{2} / \mathrm{a}$ and $8 \mathrm{kWh} / \mathrm{m}^{2} / \mathrm{a}$ in 2014 . Fig. 7 presents the average monthly values for lighting consumption per $100 \mathrm{~m}^{2}$ after calculating the mean differences. The simulation result was used to assess the presented profiles in Fig. 5. The simulated monthly electric lighting profiles did not identically match the calculated values in Fig. 6. There is a $20-30 \%$ variation between electric lighting consumption in the summer and winter seasons. This is mainly due to solar access (angles) and daylighting autonomy variations between summer and winter.

\section{Discussion}

\subsection{Summary of main findings}

Key results of the data acquisition indicate that the efficiency of lighting and associated fossil fuel and GHG reduction are lower than expected. Installation of fluorescent and compact fluorescent lamps led to only 35-40\% reduction in lighting power consumption between 1994 and 2014. Further comparisons of annual lighting power density report the real measures consumption change in average from $14 \mathrm{kWh} / \mathrm{m}^{2}$ to $8 \mathrm{kWh} / \mathrm{m}^{2}$. More importantly, the study proofs that the quality of fluorescent ballast and lamps sold in Egypt are respectively less energy efficient than the minimum requirements specified in the EU Directive [8]. Based on the study findings, we recommend quality control and market supervision for the CFL and LED lamps. 


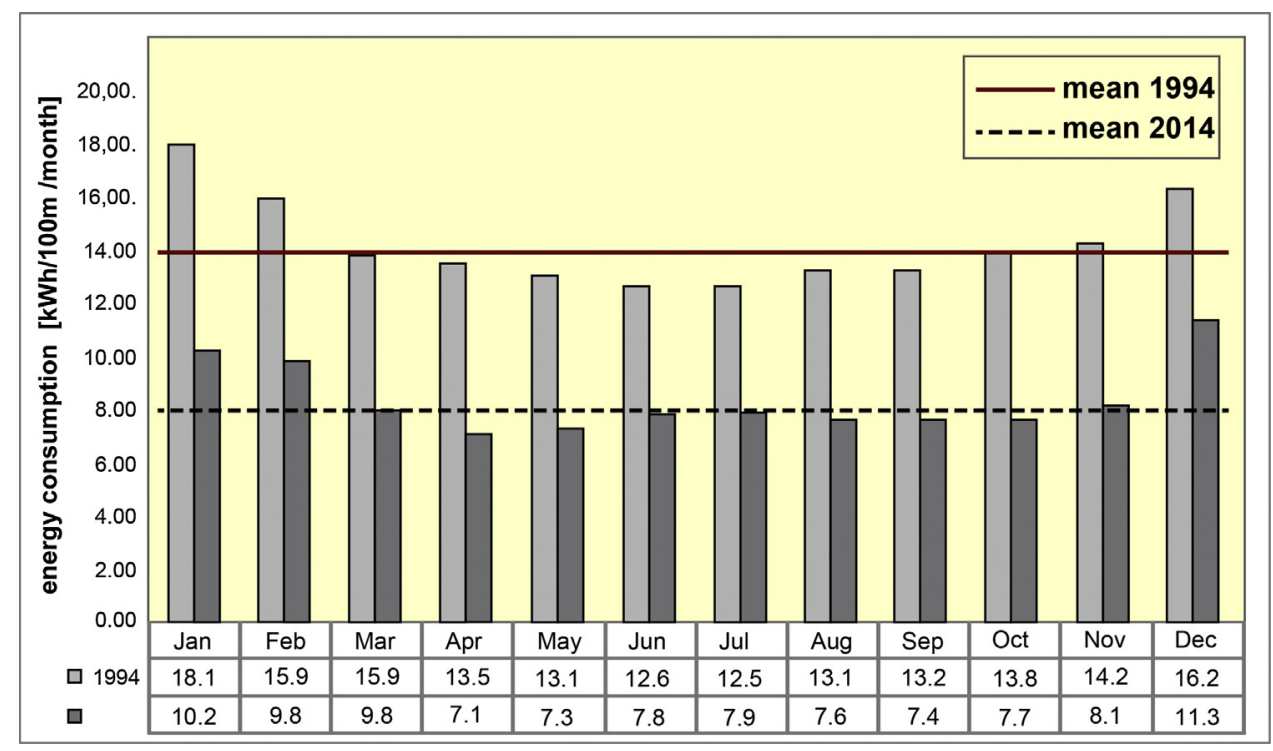

Fig. 7. Comparison results of average electric monthly lighting energy consumption of the years 1994 and 2014.

We quantified the improvement of lighting energy efficiency in Egyptian middle class households over the last 20 years. The increase of energy efficiency, associated with the installation of CFL and fluorescent lamps was expected. There was missing data on the real improvements. According to the Energy Efficiency Improvement and Greenhouse Gas Reduction Project program the energy saving potential of replacing incandescent lamps in Egyptian households was estimated to exceed $50 \%$ [8]. However, average lighting consumption declined over time by only $35-40 \%$, with significant decreases between examination years 1993-1998 (Dataset I) and 2009-2014 (Dataset II). Replacing incandescent lamps with CFL and fluorescent lamps was positively associated for all examined apartments with energy savings. Across the year 2014, electric energy consumption for lighting has significantly lower consumption values. The full sample had an average energy consumption of $8 \mathrm{kWh} / \mathrm{m}^{2} / \mathrm{a}$ for electric lighting. Over a period of 20 years all apartment occupants phased out their incandescent lighting lamps. The average consumption for electric lighting in 1994 was $14 \mathrm{kWh} / \mathrm{m}^{2} / \mathrm{a}$. As shown in Table 3, the number of CFLs per household in 2014 is substantially high (50\%). On the other side, the 2014 audit results indicated that occupants still prefer incandescent lighting, since $20 \%$ of lamps are incandescent. This is due to its slightly lower color temperature (Color Rendering Index (CRI)) in living rooms, guest and study areas. Surprisingly, the study revealed that the average plug load power intensity increased by $40 \%$ moving from $12 \mathrm{~kW} / \mathrm{m}^{2} / \mathrm{a}$ for Dataset I to $16 \mathrm{~kW} / \mathrm{m}^{2} / \mathrm{a}$ in Dataset II. The appliance inventory confirms the increase (penetration and saturation) of appliances across all apartments (see Table 4).

\subsection{Strengths and limitations of the study}

For this study, we developed a methodology that could be used by other researchers. On-site audits, collected monthly bills, simulation and electric plug loads calculation enabled us to report the real electric lighting performance of 150 apartments. We provided accurate data to inform timely decision makers. This study builds on earlier studies that have documented the energy consumption in residential buildings in Egypt [29,38,25,39-43]. None of these studies, however, provided detailed lighting energy characteristics of residential apartments. Therefore, the presented outcome can be very helpful for energy modelers and decision makers to better understand the building performance analysis through benchmarking and can help in estimating the real impact of energy efficiency measures in the Egyptian residential building sector. The strength of this study includes the use of complete, detailed, longitudinal monthly consumption data over 20-year time span and standardized measures of electric energy consumption using energy meters, including estimates of appliances and lighting fixtures types, power, and profiles made with data acquisition and modeling techniques with known reliability and validity. The aim of the study was to quantify and track the changes and improvements of lighting energy efficiency using real measured data. Thus in this study, we were explicitly not interested in the daylighting harvesting strategies $[44,45]$. Nonetheless, using a specific sample and combining evidence based approach with simulation we identified the energy savings accurately and created a monthly consumption profile. Our findings contribute to literature on energy efficient lighting and the quantification of energy savings in the residential building sector [46], in particular we consider this research results beneficial and transferable to other Middle East and North Africa (MENA) region countries through bodies such as the Energy efficiency in the construction Sector in the Mediterranean (MED-ENEC) [47]. The main two strategies reported in our audit for reducing energy use for electric lighting were the CFL and fluorescent lamps. We found that the efficiency of lighting and associated fossil fuel and GHG reduction are lower than expected. Our findings showed that the installation of fluorescent and compact fluorescent lamps led to a $35-40 \%$ reduction in lighting power consumption over a period of 20 years. Our findings are not in line with literature review and research that assumes an expected saving or $50-70 \%$ of the original lighting input $[8,13]$. Despite that the reason of this mismatch is out of our study scope, we assume that the mismatch could be due to the quality of fluorescent ballast and lamps sold in Egypt. According to UNDP Project, on average fluorescent lamps and ballasts are respectively $10 \%$ and $30 \%$ less energy efficient than the minimum requirements specified in the EU Directive [8]. For example, it is conservatively assumed that the CFLs last for an average of $4700 \mathrm{~h}$ (life-spans of up to $8000 \mathrm{~h}$ are quite normal for high-quality CFLs) but for various reasons a lower lifespan is assumed in Egypt [8]. Therefore, it is necessary to deal with the problem of lamps imports. Lighting fixtures should be imported from internationally recognized companies that comply with European standards and specifications after being subjected to thorough testing and examination. 
Despite these strengths, this study had some limitations. The estimation of the plug loads power density does not imply measuring. We used the audits to estimate the plug loads and subtract their values from the monthly electric bills assuming a constant monthly plug load. Future studies can benefit from measuring and monitoring tools such as current transformer meters, shunt (smart plugs) and micro metering loggers to identify the plug loads.

The study was limited due to its self-reported audits and changes in the apartment occupancy rates and intensity, and we could not completely control for misreporting, which may have resulted in over or under reporting of lighting efficiency. Similarly, we do not have an annual audit or monitoring for the 20 years period. So the audit results represent only one year examination (2014) of 150 apartments. Analyses of consumption could be also limited by electric heating effects that could be occasionally happening despite not having any heating device in the selected apartment's sample. It is important to mention that many of possible unknown changes happened over the long study period of 20 years. Those changes were not monitored for this study and could be influential. Therefore we consider electric fixtures, occupant behavior, and life style habits as independent variables which have not been considered in this research.

\subsection{Implications for practice and future research}

In summary, this study provides a quantified evidence of energy efficient lighting savings and power density in the Egyptian residential sector. Egypt and the EU will enter into a free trade agreement by 2019. The Egyptian government plans to distribute 50 million LED lamps before 2017. Thus the cumulative direct GHG reduction benefits energy-efficient lighting programs had to be estimated in Refs. [48,13]. According to Fig. 1, the Egyptian market is potentially ready to increase the annual share of LED lamps up to 50 million lamps before 2019, when the energy subsidies are expected to become fully lifted. Therefore, lighting energy savings from LED lamps can be very significant and of high value. Overall they represent $13 \%$ of projected national electricity demand by 2020 and $17 \%$ by 2030 [8]. In the future, the estimation of energy efficiency lighting over expected lifetime of the appliances needs to be accurately quantified. Note that the expectation is that sales of incandescent would be completely phased out by 2020 . Already the share of incandescent lamps declined in the sales of 2016 and was estimated around $18 \%$ (see Fig. 1). Therefore, it is vital to source only high quality CFLs and LED lamps. As more and more manufacturers enter the Egyptian market, consumers will find it increasingly difficult to differentiate low-quality lamps from high-quality lamps, and the reputation of CFLs could suffer as a result [48]. The Ministry of Electricity stated that 2.4 million LED bulbs are inconsistent with Egypt's national electricity network specifications. The lamps were imported as part of a tender. For instance the Ministry of Electricity planned to supply 10 million LED bulbs to the domestic market [49-52].

In order to achieve optimal lighting energy efficiency and to reach its full potential of GHG reduction, the MENA region needs to close the entire gap identified in Fig. 3 and discussed earlier in Section 2.3. This requires stipulating new policies that enforce quality control through testing labs and market supervision. The following polices should be addressed as soon as possible in Egypt and all MENA regions:

1. Establish national or regional laboratory to verify compliance with standard IEC 62612 for self-ballasted led lamps and IEC 60969 for self-ballasted compact fluorescent lamps. Lighting monitoring, verification and enforcement activities should be executed by national quality control center(s). This include the development of procurement specifications and testing standards to ensure that reliable, high quality and efficient products.

2. Provide technical training and support to market control authorities and customs with a focus on imported LED lamps and components.

3. Develop national baseline, impact indicators, data collection system to ensure reliability of savings and efficiency improvements. Creating baseline typologies for dwellings, hotels, offices and educational buildings can help to characterize the building stock and guide decision makers on the priorities for lighting savings potential.

4. Implementation and support of governmental and private sector demonstration projects for targeted use of lighting controls and high efficacy lamps could increase the market penetration.

Besides the above recommended policies, future research is needed to continue tracking and analyzing the impact of using high quality lighting fixtures. The future research should consider the rebound effect, and their real saving potential.

\section{Conclusion}

Serious effort has been made in order to minimize the energy consumption of lighting installations in the MENA region. This effort has evolved, along with the development of florescent lamps, compact florescent lamps and more recently LED lamps. The objective of this paper was to quantify the effect of implementing energy efficiency policies and the benefits of actual energy savings of energy efficient lighting measures. A case study of 150 apartments in Cairo was used to measure and verify the lighting energy savings. The study findings present a novel quantification of the real effect of replacing incandescent light bulbs with CFL over a period of 20 year period and identify the performance gap. The major research findings were as follows:

(1) Installation of fluorescent and compact fluorescent lamps resulted only in a 35-40\% reduction in lighting power consumption between 1994 and 2014 instead of the estimated $50-70 \%$ reduction.

(2) Comparisons of annual lighting power density between 1994 and 2014 revealed a consumption increase due to rebound effect.

(3) Egyptian middle-income households (with ACs) have in average 15 light bulbs. The bulbs 'energy consumption account for approximately $15 \%$ of annual household electricity bills.

(4) Various energy-saving behaviors of the household occupants were identified.

(5) There is a limited penetration of LED lamps in Egyptian households, as new energy efficient lighting fixtures types.

Failing to address the previously mentioned study findings can jeopardize the UN objectives (i.e., climate change and energy savings goals) that need to be met by 2020. The introduction of high-quality LED lamps in the MENA region can significantly attenuate the lighting energy consumption that occurs in most households.

\section{Acknowledgements}

This work was supported by the UNDP project: Improving the energy efficiency of lighting and other building appliances. The authors sincerely appreciate the cooperation of the South Cairo Electricity Company, Maadi District and residents of the monitored apartments, and the other collaborators and researchers who helped throughout the project. 


\section{References}

[1] IEA, SHC Task 50 Advanced Lighting Solutions for Retrofitting Buildings, 2013, Retrieved from http://task50.iea-shc.org. (Accessed 10 May 2017).

[2] CAPMAS, Statistical Yearbook, Housing Central Agency for Public Mobilization and Statistics, Cairo, 2015, p. 16, Retrieved from http://www.capmas.gov.eg/ Pages/StaticPages.aspx?page_id=5034. (Accessed 10 December 2016).

[3] EEUCPRA, Egyptian Electric Utility and Consumer Protection Regulatory Agency, Annual Report 2013/2014, EEUCPRA, Cairo, 2014, Retrieved from http://egyptera.org/ar/elec_report.aspx. (Accessed 10 December 2016).

[4] GEF, GEF Country Portfolio Evaluation: Egypt 1991-2015, GEF Evaluation Office, 2015, Retrieved from https://books.google.be/ books?hl=nl\&lr=\&id=BIWCKd8CKKCC\&Oi=fnd \&pg=PR7\&da=CEF+Country+Portfolio+Eval uR\&sig=VZ3dGYiADVNAZdPKF32ddtARYdY. (Accessed 10 December 2016).

[5] EEHC (2014, September 10). Egyptian Electricity Holding Company tender to import 10 million energy saving LED types lamps. American Chamber Of Commerce in Egypt. Cairo. Retrieved from http://www.amcham.org.eg/ online_services/tas/View_Projects_Email_twitter.asp? project_id=32675. (Accessed 10 December 2016)

[6] K. Youssef (2015, November 16). Interview with Kamelia Youssef Consultant for Lighting Component, Ministry of Electricity and Energy UNDP-GEF, Egypt. Retrieved from http://ifpinfo.com/Top-MiddleEast-NewsArticle-6896\#. Vl3YMHarS70. (Accessed 10 March 2017).

[7] I. Yassin (2015, September). Market Development of Compact Fluorescent Lamps in Egypt. P30 presented at the Transition to Energy-Efficient Lighting in the Middle East and North Africa, Cairo. Retrieved from http://www. enlighten-initiative.org/NewsEvents/RegionalWorkshops/

TheTransitiontoEnergy-EfficientLightingintheMiddleEastandNorthAfrica. aspx. (Accessed 10 April 2017).

[8] UNDP, Improving the Energy Efficiency of Lighting and Other Building Appliances, 2011, Retrieved from http://www.undp.org/content/dam/undp/ documents/projects/EGY/00060162_Final\%20Draft\%20\%20Project\%20Document.pdf. (Accessed 10 December 2016).

[9] I. Abdel Gelil, Regional Report on Efficient Lighting in the Middle East and North Africa, UNEP-GEF, Cairo, 20111-52, Retrieved from http://www. enlighten-initiative.org/portals/0/documents/country-support/regionalworkshops/Regional\%20Report\%20MENA\%20Final.pdf. (Accessed 10 December 2016).

[10] M.A. Al-Batanony, G.M. Abdel-Rasul, M.A. Abu-Salem, M.M. Al-Dalatony, H.K. Allam, Occupational exposure to mercury among workers in a fluorescent lamp factory, Quisna industrial zone, Egypt, Int. J. Occup. Environ. Med. 4 (July) (2013) 219-249

[11] T. Ueno, F. Sano, O. Saeki, K. Tsuji, Effectiveness of an energy-consumption information system on energy savings in residential houses based on monitored data, Appl. Energy 83 (2) (2006) 166-183.

[12] M.P. Deru, N. Blair, P.A. Torcellini, Procedure to Measure Indoor Lighting Energy Performance, National Renewable Energy Laboratory, 2005, Retrieved from http://www.nrel.gov/docs/fy06osti/38602.pdf. (Accessed 10 December 2016).

[13] M. Dubois, AAke. Blomsterberg, Energy saving potential and strategies for electric lighting in future North European, low energy office buildings: a literature review, Energy Build. 43 (10) (2011) 2572-2582.

[14] N. Khan, N. Abas, Comparative study of energy saving light sources, Renew. Sustain. Energy Rev. 15 (1) (2011) 296-309.

[15] R. Saidur, Energy consumption, energy savings, and emission analysis in Malaysian office buildings, Energy Policy 37 (10) (2009) 4104-4113.

[16] P. Bertoldi, B. Atanasiu, Residential lighting consumption and saving potential in the enlarged EU, Proceedings of 4th International Conference on Energy Efficiency in Domestic Appliances and Lighting (EEDAL'06) (2006) 21-23, Retrieved from http://www.enerlin.enea.it/doconline/documents/Bertoldi. pdf. (Accessed 10 December 2016).

[17] M.A. El Mohimen, G. Hanna, M. Krarti, Analysis of daylighting benefits for office buildings in Egypt, J. Sol. Energy Eng. 127 (3) (2005) 366-370.

[18] IES, TM-24-13, An Optional Method for Adjusting the Recommended Illuminance for Visually Demanding Tasks Within IES Illuminance Categories P Through Y Based on Light Source Spectrum Standard, Illuminating Engineering Society, 2013, ISBN: 9780879952754.

[19] DOE, History of the Light Bulb, 2013, Retrieved from: http://energy.gov/ articles/history-light-bulb. (Accessed 13 November 2016).

[20] M. Stokes, M. Rylatt, K. Lomas, A simple model of domestic lighting demand, Energy Build. 36 (2) (2004) 103-116

[21] J. Deltour, P. D'herdt, A. Deneyer, M. Bodart, Impact of lighting renovation on energy consumption and visual comfort: a case study in social dwellings, Light Eng. 19 (3) (2011) 18.

[22] J. Van den Akker, Energy Efficiency Improvement and Greenhouse Gas Reduction Project (FINAL EVALUATION), UNEP-GEF, Cairo, 2010, pp. 1-52, Retrieved from http://www.thegef.org/gef/sites/thegef.org/files/gef_prj_docs/ GEFProjectDocuments/MandE/TER/FY2010/UNDP/267/267_452_TE_CCM. Egypt.pdf. (Accessed 10 May 2017).

[23] HBRC, 2005. Egyptian code for energy efficiency improvement in residential buildings, ECP306. Cairo.

[24] P. Bampou, Green buildings for Egypt: a call for an integrated policy, Int. J. Sustain. Energy (2016) 1-16.

[25] E. Khalil, Baseline Study for Egypt. Energy Efficiency in the Construction Sector in Mediterranean, Energy Research Center Faculty of Engineering, Cairo University, Cairo, 2006, Retrieved from http://s3.amazonaws.com/
zanran_storage/www.med-enec.com/ContentPages/17439177.pdf. (Accessed 10 December 2016).

[26] S. Attia, A. De Herde, et al., Impact and potential of community scale low-energy retrofit: case study in Cairo, International SASBE Conference (2009), Retrieved from http://www.researchgate.net/profile/Andre_Herde/ publication/228656160_Impact_and_potential_of_community_scale_lowenergy_retrofit_case_study_in_Cairo/links/5465e2d90cf25b85d17e46f5.pdf. (Accessed 10 December 2016).

[27] UNDP, Developing an Efficient Lighting Strategy, UNEP-GEF, 2012, p. 155, Retrieved from http://learning.enlighten-initiative.org/ebook/en/mobile/ index.html $\# \mathrm{p}=2$. (Accessed 10 December 2016).

[28] EEHC, Energy Efficiency Project for Lighting \& Home Appliances, Energy

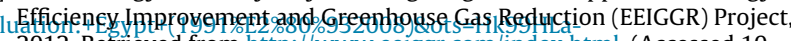
2012, Retrieved from http://www.eeiggr.com/index.html. (Accessed 10 December 2016).

[29] S. Attia, A. Evrard, E. Gratia, Development of benchmark models for the Egyptian residential buildings sector, Appl. Energy 94 (2012) 270-284

[30] M.M. Nassief, Evaluation of electricity consumption of a residential flat in Egypt, Am. J. Electr. Power Energy Syst. 3 (2) (2014) 37-44.

[31] C. Banhardt, Development of a prototype for solar powered air conditioning for apartments in El Gouna, in: Presented at the Community Forum El Gouna 2030, TU Berlin Campus El Gouna, 2015.

[32] ASHRAE, Cairo International Weather for Energy Calculations, ASHRAE, IWEC, Atlanta, 2009, Retrieved from http://apps1.eere.energy.gov/buildings/ energyplus/cfm/weather_data3.cfm/region=1_africa_wmo_region_1/ country $=E G Y /$ cname=Egypt. (Accessed 10 December 2016).

[33] W. Köppen, R. Geiger, W. Borchardt, K. Wegener, A. Wagner, K. Knoch, et al., Handbuch der klimatologie, vol. 3, Gebrüder Borntraeger, Berlin, Germany, 1930, Retrieved from https://www.climond.org/Public/Data/Publications/ Koeppen_1936_GeogSysKlim.pdf. (Accessed 10 December 2016).

[34] S. Attia, E. Gratia, A. De Herde, J.L. Hensen, Simulation-based decision support tool for early stages of zero-energy building design, Energy Build. 49 (2012) 2-15.

[35] US Department of Energy, EnergyPlus Energy Simulation Software, 2015, Retrieved from http://app1.eere.energy.gov/buildings/energyplus/ energyplus_about.Cfm. (Accessed 10 December 2016).

[36] ANSI/ASHRAE, Standard method of test for the evaluation of building energy analysis computer programs, american society of heating, Refrigerating Air-Cond. Eng. (2011) 272.

[37] R. Judkoff, J. Neymark, International Energy Agency Building Energy Simulation Test (BESTEST) and Diagnostic Method, National Renewable Energy Lab, Golden, CO (US), 1995, Retrieved from http://www.osti.gov/ scitech/biblio/90674. (Accessed 10 May 2017).

[38] G. Hanna, N.M. Guirguis, H.S. Osman, M.A. Hussein, Energy analysis for new residential buildings in Egypt, in: International Future Vision and Challenges for Urban Development Conference, Cairo, 2004.

[39] D.E. Khalil, A.A. Medhat, E.E. Khalil, Energy modeling of modern residence in Egypt, in: ASME 2012 International Mechanical Engineering Congress and Exposition, American Society of Mechanical Engineers, 2012, pp. 107-116, Retrieved from http://proceedings.asmedigitalcollection.asme.org/ proceeding.aspx?articleid=1751841. (Accessed 10 December 2016).

[40] E. Kazakevicius, A. Gadgil, D. Vorsatz, Residential lighting in Lithuania, Energy Policy 27 (10) (1999) 603-611.

[41] B.F. Mills, J. Schleich, Why don't households see the light? Explaining the diffusion of compact fluorescent lamps, Resour. Energy Econ. 32 (3) (2010) 363-378.

[42] E. Vine, D. Fielding, An evaluation of residential CFL hours-of-use methodologies and estimates: recommendations for evaluators and program managers, Energy Build. 38 (12) (2006) 1388-1394.

[43] Q. Zhang, Residential energy consumption in China and its comparison with Japan, Canada, and USA, Energy Build. 36 (12) (2004) 1217-1225.

[44] M.A. Hegazy, S. Attia, An investigation into the influence of external walls reflectivity on the indoor daylight availability in desert climates, Conference Proceedings: Building Simulation and Optimization 2014 (2014), Retrieved from http://orbi.ulg.ac.be/handle/2268/169283. (Accessed 10 March 2017).

[45] M. Hegazy, S. Attia, J. Moro, Parametric analysis for daylight autonomy and energy consumption in hot climate, 13th Conference of International Building Performance Simulation Association (2013) 2232-2240, Retrieved from http://www.ibpsa.org/proceedings/BS2013/p_2261.pdf. (Accessed 10 December 2016)

[46] H. Sallami, Analysis of Energy Use Intensity in Residential Buildings in Jordan (Master Thesis), German Jordanian University, Amman, 2015.

[47] J. Koch, S. Gouda, M. Seyppel, K. Wiesegart, F. Visser, Energy Efficient Lighting Guidelines and Recommendations for the MENA Region, MED-ENEC, Cairo, 2014, p. 32, Retrieved from http://www.med-enec.eu/sites/default/files/user_ files/downloads/Lighting\%20Brochure\%20Final.pdf. (Accessed 10 December 2016).

[48] E. Martinot, N. Borg, Energy-efficient lighting programs: experience and lessons from eight countries, Energy Policy 26 (14) (1998) 1071-1081.

[49] Alwatan (2014, October 21). Wakil Al Kahrabaa: Al Lambaat Al-muwafira tuhaddid bikarissa. Cairo. Retrieved from http://www.elwatannews.com/ news/details/580850. (Accessed 10 December 2016).

[50] Wellmax (2014, October 13). Egypt Imports 2.4 Million LED Bulbs Don't Conform With Electricity Network. Retrieved from http://wellmaxgroup.com/ egypt-imports-2-4-million-led-bulbs-dont-conform-with-electricitynetwork/. (Accessed 10 May 2017). 
[51] M. El Sewedy (2014, July 5) in Arabic. Itihad Al Sina'at: 70 million lamba hajm al suk sanawiyann mu'azamha mukhalif lilmuwasafat. Retrieved from http:// www.almasryalyoum.com/news/details/441916. (Accessed 10 April 2017).

[52] M.H. Hilal, LED Lamps Account for $80 \%$ of the Market Sales, (in Arabic), Almal News, 06 Mach, 2016, Retrieved from http://www.almalnews.com/Pages/ StoryDetails.aspx?ID=325067. (Accessed 10 May 2017).
[53] UNDP, Global Lighting Map, UNEP-GEF, 2016, Retrieved from http://map. enlighten-initiative.org/. (Accessed 24 August 2017). 